\title{
New Approaches in Managing Tourism Higher Education to Produce The Graduates with The Competitiveness in the Era of ASEAN Economic Community
}

\author{
Ahmad Junaedi Abas \\ Trisakti School of Tourism \\ Jakarta, Indonesia \\ djunaediabbas@stptrisakti.ac.id
}

\author{
Besty Puspa Yustika \\ Trisakti School of Tourism \\ Jakarta, Indonesia \\ yustika@stptrisakti.ac.id
}

\begin{abstract}
Facing the uncertainty of the changes taking place on the application of Asea Economic Community (EAC) at the end of December 2015, this paper discusses what EAC impact on higher education institutions, particularly the higher education institutions of tourism in Indonesia. What strategy should be done in the management of higher education institutions of tourism to be able to produce graduates who excel and have competitiveness in the face of competition occurs not only at the national and regional level, but also at the global level.

Over the past two decades, higher education institutions in Indonesia, especially in tourism higher education institutions face many environmental changes that are increasingly rapid and significant impact on the institution. The changes are both from macro and micro environment. Enforcement of the Asean Economic Community (AEC) is one of the Asean regional policy that will inevitably bring changes and impact on the member countries of ASEAN, including Indonesia, particularly on the management of educational institutions.

Achievement of ASEAN economic integration through the AEC, based on the AEC Blueprint that includes four key pillars: (1) single market and productivity base, (2). Competitive Economic Region, (3). Equitable Economic Development and (4). Integration into the Global Economy. Brought to the four pillars requires Indonesia to be ready to make changes, especially in the strategy of improving the quality of human resources. In the blueprint, also designated 12 priority sectors to be integrated. Seven are goods sector and the other five are the services sector including the tourism sector.

This paper analyzes the changes that occur as a result of the implementation of the AEC on the tourism sector, especially in the higher education institutions of tourism. Further identified various new, more strategic approach in order to be able to produce human resources that have advantages and competitiveness to face the opportunities and challenges that arise in the era of the current and future AEC.
\end{abstract}

Keywords-ASEAN Economic Community, Tourism, Higher Education, Managing Higher Education, Competitiveness.

\section{INTRODUCTION}

One topic that is often discussed in recent years by various groups including academics is about the implementation of ASEAN Economic Community (AEC) in December 2015. One of the questions that often arise in the discussion is what AEC impact on Indonesia? Some discussion leads to the question of what impact the AEC to higher education institutions in Indonesia, but not a lot of discussion led to a discussion of how higher education institutions respond and set a strategy in managing the institution to be able to face the changes that occur as a result of the implementation of the AEC.

Southeast Asia has a regional organization called ASEAN. ASEAN was established in 19671 with a focus on issues of security and peace in Southeast Asia. Starting from the five founding countries, namely Indonesia, the Philippines, Malaysia, Singapore and Thailand, now consists of ten ASEAN Countries join later, namely Brunei Darussalam (1984), Vietnam (1995), Myanmar and Laos (1997), and Cambodia (1999).However, with the passage of time and changes in growing regional strategic environment, ASEAN also focus on economic issues, which carries the spirit of economic and social stability in the region through accelerated economic growth, social progress and culture by promoting equality and partnership. Shifting the issue is particularly clear when in 1997, the economic crisis in Thailand, as the impact of globalization and financial integration of the world. The economic crisis then spread to the member countries of ASEAN such as Indonesia, Malaysia and Singapore. To that end, ASEAN as a regional organization in the region, is also actively responded to the spirit of cooperation which is known as a regional self-help.

ASEAN above steps in line with global demand that is characterized by the proliferation of forms of economic and financial integration in the various regions. Take for example, European, regional integration begins with economic integration (real sector), followed by monetary integration and ending with the formation currency Euro.2 In the African region also has a regional institution (CFA Franc Zone and Gulf Area), which served to integrate the regional economy and formed and a common currency. That is, although in the Southeast Asian region has not raised a common currency, but 
ASEAN as a leading sector in the form of regional integration, efforts agreements, including the ASEAN Community in 2015. ASEAN Community 2015 is an agreement on the establishment of a community that consists of three pillars, namely the AEC (ASEAN Economic Community), the ASEAN Security Community (ASEAN Security Community) and the SocioCultural ASEAN (ASEAN Socio-cultural Community). These pillars are related to each other and mutually reinforcing objectives achievement of sustainable peace, stability as well as the distribution of welfare in the region.

In realizing the "dream", the implementation of the first pillars of the ASEAN Community in 2015 (ie the economic dimension) are increasingly free and open flow of goods, services, investment, skilled labor and capital flows in 2015 in the future. This is consistent with the ultimate objective of economic integration as envisioned in the ASEAN Vision 2020.

\section{AEC IMPACT ON INDONESIA}

Looking at the current condition of Indonesia, the implementation of the AEC will certainly have an impact on various aspects of Indonesian life and policies of the Indonesian government to be able to adapt, set a strategy to gain the maximum benefit from the establishment of AEC. The implementation of the AEC will have an impact on government policy in Indonesia in the future.

There are four things that will be the focus of the AEC in 2015 which can be used as a good momentum for Indonesia. First, countries in Southeast Asia will be used as a unified region market and production base. With the creation of the unity of the market and production base will make the flow of goods, services, investments, large amounts of capital, and skilled labor becomes no barrier from one country to another country in Southeast Asia. Its impact on Indonesia is in terms of the readiness of Indonesia to produce products that have the competitive edge to capitalize on these opportunities as a means of strengthening the country's economy. This ability can only be realized through improving the quality of human resources and superior competence. Thus, the system of human resource development in Indonesia, both formal and non-formal, it should be managed properly and refers to regional and international standards

Second, the AEC will be established as an economic region with a high level of competition, which requires a policy that includes competition policy, consumer protection, Intellectual Property Rights (IPR), taxation, and E-Commerce. Thus, it can create a climate of fair competition; there is protection in the form of a network system of consumer protection agencies; prevent copyright infringement; creating an efficient transport network, secure, and integrated; eliminating the Double Taxation system, and; increase trade with online-based electronic media. This policy requires the Indonesian government to be able to apply a transparent economic policies with good governance.

Third, the AEC will serve as the region has equitable economic development, with priority on Small and Medium Enterprises (SMEs). Competitiveness and dynamism of SMEs will be improved by facilitating their access to the latest information, market conditions, and development of human resources in terms of capacity building, finance, and technology.

Fourth, the AEC will be fully integrated to the global economy. By building a system to improve coordination of the member states. In addition, there will be increased participation of countries in Southeast Asia in the global supply chain through the development of a package of technical assistance to countries less developed ASEAN members. This is done to improve the capabilities and productivity of the industry so that not only enhancing their participation in a regional scale but also raises initiatives for globally integrated.

Based on the ASEAN Economic Blueprint, AEC become indispensable for reducing disparities among ASEAN member countries in terms of economic growth through increased interdependence. AEC can develop the concept of metanational in the food supply chain, and become a single trading bloc to deal and negotiate with the exporters and importers of non-ASEAN.

For Indonesia, the AEC will be a good opportunity, because of trade barriers will tend to diminish even be non-existent. This will impact on increasing exports, which in turn will increase the GDP of Indonesia. On the other hand, emerging new challenges for Indonesia in the form of commodities traded homogeneity problems, for example for agricultural commodities, rubber, wood products, textiles, and electronics [1].

In this case, the risk of competition will appear with the number of imported goods will flow in large numbers to Indonesia, which will threaten the local industry in competing with foreign products that have better quality. This, in turn, will increase the trade deficit for Indonesia.

On the investment side, this condition can create a climate that supports entry of Foreign Direct Investment (FDI), which can stimulate economic growth through technology development, job creation, human resource development (human capital) and easier access to the world market. Even so, the condition can raise risk exploitation. Indonesia still has a level of regulation that is less binding that can cause large-scale act of exploitation in the availability of natural resources by foreign companies into Indonesia as the country with the abundant natural resources compared to other countries. There is a possibility also exploitation of foreign companies could damage the ecosystem in Indonesia, while the regulation of investment in Indonesia has not been strong enough to keep the natural conditions, including the availability of natural resources contained.

\section{AEC IMPACT ON TOURISM EDUCATION INSTITUTION IN INDONESIA}

As explained in the previous description that the implementation of the AEC received special attention by all members States, including Indonesia. Various studies conducted to predict the impact on each country. Some are optimistic, some pessimistic. Regardless of perceptions of the various parties in Indonesia, the AEC has rolled and will continue to achieve the vision that has been set. 
The first pillar of the four pillars as the basis for the establishment of AEC, signaled the liberalization of trade in goods, services, investment, skilled labor and capital flow freely freer, one of which is the liberalization of skilled labor. This indicates will open greater opportunities for skilled labor in the area of AEC to work in a variety of AEC member countries, as long as they fulfilled the criteria for skilled labor. In the book "Towards the ASEAN Economic Community 2015" issued by Ministry of Commerce of the Republic of Indonesia (2014) pointed out that "The challenges arising from the implementation of the ASEAN Economic Community (AEC) by the end of 2015 signaled the liberalization of trade in goods, services, investment, labor skilled freely, and free capital flow. Definition of skilled labor are the workers who have the expertise, specialist skills, knowledge and expertise in his field, which can be obtained from the institution or the ability of informal acquired from informal educational institutions or work experience".[2]

To support the free flow of skilled labor, then drafted mutual recognition arrangement (MRA). MRA can be interpreted as an agreement with all ASEAN members to accept some or all aspects of the assessment results such as test results or certificate. The purpose of the MRA is to create mechanisms and accreditation procedures to get a similarity / equality and recognizes the differences between countries for education, training, experience and licensing requirements for professionals who want to work.

As explained by Pyakurel (2014) that "The implementation of AEC in 2015 will significantly increase intra - regional flow of people (workforce, tourists, graduates, and students) in ASEAN countries.

The issue with the intra - regional movement of university graduates among the ASEAN countries is that there is a lack of common standard to assess the skills of these graduates. For instance, graduates from Thailand may have opportunity to work in other ASEAN member countries and similarly graduates from other ASEAN countries may have opportunity to work in Thailand. However, the education systems among the ASEAN countries are different from one another. Each university in ASEAN follows its national education system as specified by its Ministry of Education. Diversity in the ASEAN education system poses challenge to the AEC job market. It would be challenging for the market to assess the skills of graduates from different ASEAN countries".[3]. The most difficult challenge to Indonesia's education is to prepare graduates who are able to adapt, compete and capture the opportunities arising from the implementation of AEC. There are 12 priority sectors in the AEC, which is divided into two parts, namely seven industrial goods sector and five from the service sector. One of the services sector is tourism.

The entry of tourism services sector as a priority, meaning that tourism education institutions in Indonesia should be able to move quickly and to develop appropriate strategies to be able to produce graduates who are competitive. Graduates who have their advantages and competitiveness, not only intended to capture a wide range of opportunities to work abroad, but more important is to develop the tourism industry in the country to achieve the vision of Indonesian tourism as a leading sector in the country's foreign exchange income. Indonesia tourism will flourish if owned competent and superior human resources.

The critical role of Tourism Higher Education Institutions in the face of the face of the AEC in 2015, can be seen from the government's commitment as expressed in a National Coordination Meeting of Tourism Education Provider in Indonesia by the Minister of Tourism, Arif Yahya, in November 2015 explained that "tourism is also facing severe challenges in the form of competition tight, including in generating quality human resources in the ASEAN region. This is related to the implementation of ACCSTP (ASEAN Common Competency Standards for Tourism Professionals) which refers to SKKNI Indonesia ...... national tourism development will promote the Pentahelix scheme, which is involving government, academia, business, public, and media in the development of tourism in Indonesia " [4]

\section{THE PROBLEMS FACED BY TOURISM EDUCATION INSTITUTIONS}

The development of tourism industry in Indonesia triggered an increase in the number of tourism higher education in Indonesia. Based on data from the Association of Indonesian Tourism Education Institutions (HILDIKTIPARI), recorded 82 tourism education institutions registered in this association. Compared with the tourism development plan by the government, the existing size is certainly not adequate, despite uneven distribution.

However, there is no doubt that tourism higher education institutions also face various obstacles as well as other higher education institutions in Indonesia. "One of the fundamental problems faced by higher education institutions is a problem of relevance and quality are not encouraging. Higher education has not been able to bring entrepreneurs by creating job orientation and independence, ... at least we noted various fundamental constraints that exist in the world of higher education, namely: the low the quality of teachers, inadequate educational facilities, educational effectiveness problems, high cost of education, the problem of educated unemployment and link \& match between higher education and employment needs in the field. [5] (Parlementaria, 2012)

On the other hand Panday (2014) states that "international competition in education is in terms of: quality of graduates, the ability of the international language / English, ability to cooperate, quality of research, quality of the program, the ability of lecturers, and overall is a quality college, all resulting in low competitiveness of graduates. .... The main problem for Indonesia is a strategy to improve the quality of higher education, in connection with the implementation of the ASEAN Economic Community" [6]

As an illustration of Indonesia's competitiveness ranking among ASEAN member countries, as presented in Table 1. 
Tabel 1 : The Travel \& Tourism Competitiveness Index 2015

\begin{tabular}{|c|c|c|c|}
\hline $\begin{array}{c}\text { ASEAN } \\
\text { Rank }\end{array}$ & $\begin{array}{c}\text { World } \\
\text { Rank }\end{array}$ & Country & Values \\
\hline 1 & 11 & Singapore & 4.86 \\
\hline 2 & 25 & Malaysia & 4.41 \\
\hline 3 & 35 & Thailand & 4.26 \\
\hline 4 & 50 & Indonesia & 4.04 \\
\hline 5 & 74 & Philippines & 3.63 \\
\hline 6 & 75 & Vietnam & 3.60 \\
\hline 7 & 96 & Lao PDR & 3.33 \\
\hline 8 & 102 & Nepal & 3.27 \\
\hline 9 & 105 & Cambodia & 3.24 \\
\hline 10 & 134 & Myanmar & 2.27 \\
\hline
\end{tabular}

Source: World Economic Forum Report, 2015

\section{DIRECTIONS FOR THE DEVELOPMENT OF TOURISM HIGHER EDUCATION IN INDONESIA}

While the various problems faced by higher education institutions in Indonesia, the Ministry of Research, Technology and Higher Education, as a government agency that is responsible for the quality of the output of higher education institutions in Indonesia, has given direction to the development of higher education institutions in the future. This was stated in the Strategic Plan for years 2015-2019. [7]

\section{Vision}

"The realization of quality higher education as well as science and technology and innovation to support the competitiveness of the nation. Quality of higher education is intended to produce graduates who are knowledgeable, educated, and skilled, while the ability of science and technology and innovation interpreted by the expertise of human resources and $\mathrm{R} \& \mathrm{D}$ institutions and universities in conducting research, development, and application of science and technology which is supported by the construction of input factors (institutional, resources, and network). Meanwhile, the meaning of the nation's competitiveness is the contribution of science, technology and higher education in the economy shown by the excellence of the product technology R \& D results generated by the industry / company backed by R \& D institutions (LPNK, LPK, Enterprises, Universities) and skilled personnel of higher education"

\section{Mission}

In an effort to achieve above vision, the mission of the Ministry of Research, Technology and Higher Education are: 1. Improving access, relevance and quality of higher education to produce qualified human resources; and 2. improve the ability of science and technology and innovation to generate added value product innovation. This mission includes efforts to address the problem of development of science and technology and higher education in the period 2015-2019 in the aspects of learning and student affairs, institutional resources, research and development, and strengthening innovation.

\section{Strategic Goals}

In order to achieve the vision and mission the Ministry of Research, Technology and Higher Education as noted above, the vision and mission formulated into a form that is more focused and operational form of the formulation of strategic objectives (strategic goals). In order to solve the problems faced as described in the previous section in order to realize the vision and mission of The Ministry of Research, Technology and Higher Education, the strategic goals to be achieved are: "The increasing relevance, quantity and quality of human resources educated, as well as the ability of science and technology and innovation for superior power the competitiveness of nations" To see more concrete achievement of the strategic objectives need to set the size of that objective quantitative indicator. In the design of the next five years, the performance indicators measured by the index of strategic objectives of higher education by 2019 is targeted is ranked top 56 in the world with an index value of 5.0 and innovations Indonesia in 2019 targeted is ranked 26 of the world with a value of 4,4 .

\section{Strategic target}

The strategic objective is then translated into five (5) strategic targets in accordance with problems to be solved in the period 2015-2019. Strategic objectives are:

1. Increasing the quality of student learning and higher education;

2. Increasing the quality of science and technology and higher education institutions;

3. Increasing the relevance, quality, and quantity of the resources of science and technology and higher education;

4. Increasing the relevance and productivity of research and development; and

5. The strengthening of the capacity of innovation.

It is well known that tourism higher education institutions still face so many problems. However, a variety of environmental changes that occur at this time, forcing higher education institutions to intelligently respond to the various changes that occur at this time. One of the changes taking place now is a variety of changes as a result of the implementation of the AEC. Thus, managers of educational institutions should be able to apply the principles of management "do more with less" as a new approach to improve the competitiveness of the institution and graduates.

\section{DIRECTIONS FOR THE DEVELOPMENT OF COMPETITIVENESS OF THE TOURISM HIGHER EDUCATION GRADUATES}

The discussion of competitiveness is often associated with the state or the company's competitiveness. Atkinson (2013) explains that "With the increased globalization of the economy, the term competitiveness has become ubiquitous. But what does it actually mean? Most see the term as synonymous with productivity. Harvard's Michael Porter states, "The only meaningful concept of competitiveness at the national level is productivity. The World Economic Forum's Global Competitiveness Report defines competitiveness as the set of 
institutions, policies, and factors that determine the level of productivity of a country. And IMD's World Competitiveness Yearbook defines competitiveness similarly, but more broadly, as how an "economy manages the totality of its resources and competencies to increase the prosperity of its population."[7] While Leibbrandta, Gneezy and List (2013) explained that "Individuals frequently face a decision that can affect their wellbeing and even survival: to compete or not to compete. Natural and social scientists argue that competitions and the right dose of competitiveness significantly determine not only the future of the individual but even the evolution of the whole species. However, behavioral experiments with humans show that there are large differences in competitiveness between individuals that cannot be readily explained by genetic endowments, abilities, or risk attitudes. A possible explanation of the large variations in human competitiveness is based on learning theories. Observational learning describes individuals' tendency to adapt by imitating successful behavior. Social or cultural learning models attribute an important role to individual experiences in the social and physical environments for the formation of traits and norms. Thus, individual variations in competitiveness may be the result of exposure to different environments and pressures"

Bogoyavlenskaya, Diana B. and Klyueva Tver, Olga A. (2013) explained that "In the context of rising living standards, having a competitive personality is the key to success in the global competitive struggle. Contemporary multifactor models of evaluating a country's global competitiveness include an evaluation of the labor force along with economic indicators......Creating competitive specialists has become a priority for the system of education, a project embodied in the policy documents in this sphere. For instance, training a qualified employee at an appropriate level and with an appropriate profile to be competitive in the labor market is presently a priority educational standard for the new generation". [8]

Based on the explanation of the competitiveness, it can be concluded that the competitiveness can be viewed from various perspectives, from the institutions or the individual aspect. In principle, competitiveness is the ability of institutions or individuals to produce products / services that meet the needs and create satisfaction to users. In this context, the competitiveness of the institution is determined by the competitiveness of its graduates.

In connection with the tourism labor in Indonesia, Aring (2015) about ASEAN Countries-Skills mismatch in Indonesia explains that "According to a World Bank survey (2008) distributed to the nation's employers, core skills - numeracy, literacy, and other generic skills - and practical experience are perceived to be nearly as important as theoretical knowledge for professionals and skilled workers. However, the survey goes on to reveal that such skills are often lacking among managers and professionals, with English and computer competencies particularly scarce. The survey also found that behavioral skills were especially desirable in managers yet nearly one third of employers thought there was a gap among managers and professionals. The survey Findings indicate that nearly all employers from manufacturing and services expect skill requirements in their industries to rise, indicating everworsening skill shortages.

According to World Bank estimates for 2010, about 55 per cent of tertiary graduates were "overqualified" in their employment, the highest such skills mismatch in South-East Asia (Cambodia is an unlucky second, with around 48 per cent of such overqualified graduates). [9]

Youth unemployment suffers disproportionately from the skill gaps. Surveyed employers cite the youth's lack of practical experience and the poor quality of schooling. Most likely to be unemployed are secondary school and TVET graduates between 35 and 40 per cent of graduates aged 15 and older are expected to not find suitable employment. Women and youths from urban areas also have particular difficulty finding jobs. Indonesia does not suffer so much from a lack of graduates but rather, it suffers from a lack of appropriately skilled workers regardless of educational attainment. Even as university enrolment and completion rates rise, highly educated labour does not necessarily correlate neatly with highly skilled labor. Serious concerns still abound over the quality and relevance of the training that new graduates receive, which falls short of employers' expectations and needs. Additionally, companies continue to cite the lack of, and demand for, generic skills, such as behavioural skills, critical thinking, and English (EIU, 2012). [10]

To create the competitiveness of educational institutions, including tourism higher education, the government represented by the Ministry of Research, Technology and Higher Education, has given direction in the development of competitiveness, as shown in Figure.1.

Figure 1: Logical Framework to Support Competitiveness

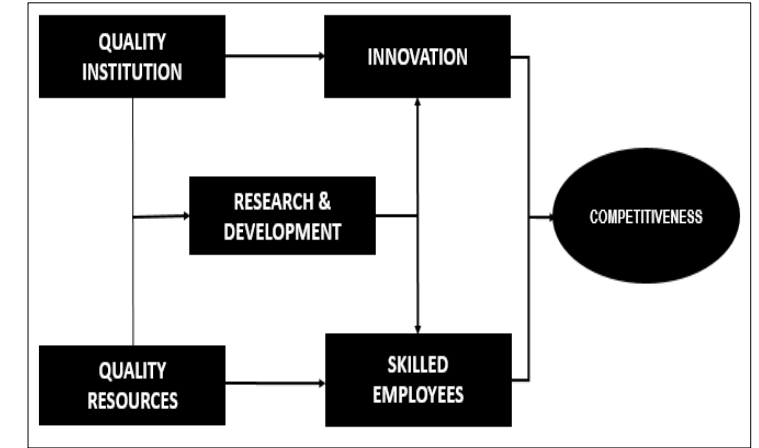

Source: Ministry of Research, Technology and Higher Education, 2015

Based on the framework of competitiveness can be concluded that, "increasing the index of higher education and innovation, there are two direct core elements that should be improved, namely innovation and a skilled workforce of Higher Education as shown in Figure 2, Two direct core element is supported by indirect core elements, namely research and development and supported by two supporting element, namely the institution of quality and quality resources. In order to realize an increase in both indices, the direct core element, indirect core element, and a supporting element this must exist 
and support each other" Ministry of Research, Technology and Higher Education, 2015)

Thus, to produce graduates as candidates for skilled labor (competitiveness), educational institutions must realize: a quality institution and a quality resources to be able to do a relevant research $\&$ development according to the needs of the institution, in order to be able create an innovation.

A keyword in creating competitiveness as described in the above framework is "quality". Thus, in the application framework of competitiveness above, in principle refers to the application of quality management. There are several types of quality management concepts and tools that can be applied by the current tourism education institutions, to be able to compete in both the national scale, regional or international.

On a national scale, the development of quality higher education can be guided by the Higher Education Quality Assurance System in Indonesia, where the evaluation was done by the National Accreditation Board of Higher Education (BAN-PT). For the ASEAN regional level, particularly for tourism education institutions can refer to the "Guide to ASEAN Mutual Recognition Arrangement on Tourism Professionals" (ASEAN, 2012). Whereas at international level, can correspond to the ISO 9001: 2015 (replacement of ISO 9001: 2008) or the latest edition of the Baldrige Excellence Framework for Education.

As a tool in quality management, there are similarities between the approach adopted by the Quality Management System of Higher Education Quality Assurance in Indonesia with ISO 9001: 2015 and Malcolm Baldrige is to improve the competitiveness of educational institutions.

Figure 2 : 2015-2016 Baldrige Excellence Framework (Education)

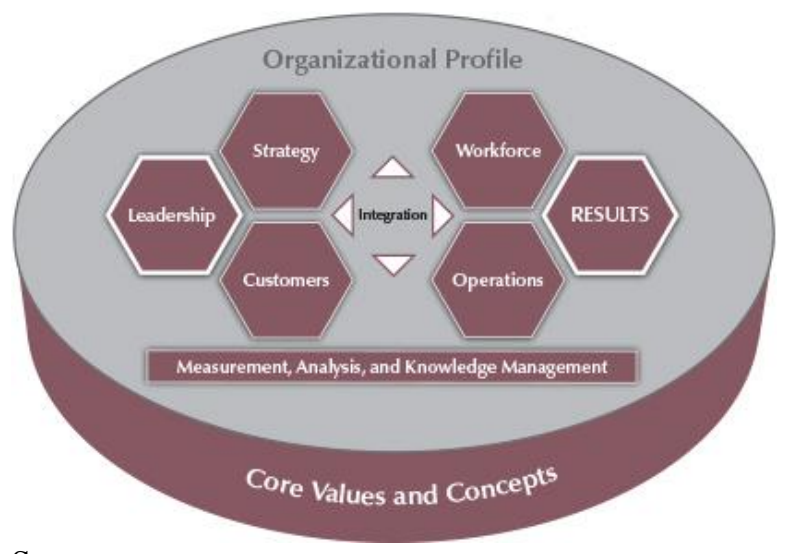

Source:

http://www.nist.gov/baldrige/publications/education_criteria.c $\mathrm{fm}$

The use of the Baldrige Framework as a tool to improve the quality and competitiveness of the institution, it can be seen from the objectives to be achieved, that is "to help organization improve and achieve excellence. The questions in the Education Criteria help you explore how you are accomplishing your organization's mission and key objectives in seven critical areas: 1.Leadership; 2. Strategy; 3. Customers; 4. Measurement, analysis, and knowledge management; 5. Workforce; 6. Operations; 7. Results." As shown in Figure 2, all the elements have to work in an integrated way. [11]

All quality management tools discussed in this paper is not new as an approach to improve the quality and competitiveness of educational institutions, especially tourism education institutions. However, referring to the various survey results show that the higher education institutions in Indonesia, including tourism education institutions, has not been able to achieve high competitiveness both at regional and international levels. This means that in the application of quality management there are still many weaknesses. Therefore, a new approach is meant in this context, is the ability to overcome major weaknesses in the application of quality management itself is a high commitment. Commitment from all stakeholders: governments, institutions, educators and support team in implementing the quality management appropriately in order to create the Institute of Tourism Higher Education with a high competitiveness, so as to produce the graduates who have the skills and competitiveness needed in an the era of AEC.

Referring to Alfred A. Marcus (2005) in his book Big Winners and Big Losers, stated that "From the history of the winners, I extract the critical attributes that contributed to their performance. Being a big winner means carrying out (i) a wellexecuted niche strategy that achieves a balance between (ii) agility, (iii) discipline, and (iv) focus. [12] This is a new approach that should be applied to tourism education institutions in Indonesia to be a winner in the competitive arena of AEC era.

\section{CONCLUTION}

Tourism is the mainstay of the sector in the country's foreign exchange revenues of Indonesia. Entry 2015 AEC should be taken positively, but also need to be aware of its impact on the competitiveness of nations. One of the pillars underlying the establishment of the AEC is the first pillar in its application will give freedom to the skilled labor to work in the member countries of ASEAN. To seize this opportunity, Indonesia should be able to improve the quality of higher education institutions in order to be able to produce the tourism human resources with competitiveness. As well as other higher education institutions, tourism higher education institutions face problems of quality and competitiveness of their graduates. Indonesia does not suffer so much from a lack of graduates but rather, it suffers from a lack of appropriately skilled workers Regardless of educational attainment. Even as university enrollment and completion rates rise, highly educated labor does not necessarily correlate neatly with highly skilled labor. Serious concerns still abound over the quality and relevance of the training that new graduates receive, which falls short of employers' expectations and needs.

So far, higher education institutions have been trying to improve tourism competitiveness and graduate institutions through the implementation of quality management. However, until now there has not been able to solve the problem of 
competitiveness of graduates. Therefore, it is deemed necessary to take a new approach, which is to increase the commitment in the implementation of quality management through a balance between agility, discipline and focus.

\section{REFERENCES}

[1] Santoso, W. et.al (2008). Indonesia Economic Outlook 20082012: ASEAN economic integration and prospects of the national economy. Jakarta: Bureau of Economic Research Directorate of Economic Research and Monetary Policy

[2] Ministry of Commerce of the Republic of Indonesia (2014) "Towards the ASEAN Economic Community 2015"

[3] Pyakurel, Shilpa (2014) "Asean Economic Community and Its Effects on University Education : A Case Study of Skill Verification By The Means of Professional Certification Examination", Thesis, The Graduacte School of Bangkok University, Thailand.

[4] Bureau of Law and Public Communication, Tourism Ministry had Indonesia,2015/ http://www.kemenpar.go.id/asp/detil.asp?c=16\&id=3025)

[5] Panday, Rorim (2014), Higher Education Quality Improvement Strategy for Strengthening the Competitiveness of Facing the
Economic Community of Southeast Asia: A Case Study, Proceedings Sociaty for Nutrition Education and Behavior (SNEB), p.1 Panday, Rorim (2014) p. 1-2

[6] Ministry of Research, Technology and Higher Education Republic of Indonesia "Strategic Plan for years 2015-2019"

[7] Atkinson Robert D. (2013). Competitiveness, Innovation and Productivity: Clearing up the Confusion, The Information Technology \& Innovation Foundation, p.2.

[8] Leibbrandta, Andreas, Gneezy, Uri and List, John A., (2013), Rise and fall of competitiveness in individualistic and collectivistic societies, Princeton University, Princeton, NJ, p.1

[9] Aring, Monika, "ASEAN Economic Community 2015: Enhancing competitiveness and employability through skill development', ILO Regional Office for Asia and Pacific, Bangkok p.61-62

[10] Economist Intelligence Unit (EIU). 2012. Skilled labour shortfalls in Indonesia, the Philippines, Thailand and Vietnam: A custom research report for the British Council (London).

[11] 2015-2016 Baldrige Excellence Framework (Education)

[12] Marcus, Alfred A. (2006) "Big Winners and Big Losers" Wharton School of Publishing- Pearson Education, Inc. p. xix. 